\title{
INITIATING SOCIAL PROTECTION SCHEME IN THE SHARING ECONOMY INDUSTRY (CASE OF INDONESIA GO-JEK RIDER)
}

\author{
Endang Yuniastuti
}

Social Welfare Science Study Program, Post Graduate Program, Faculty of Social Science and Political Science University of Indonesia, Indonesia

\section{Bambang Shergi Laksmono}

Head of Social Welfare Science Study Program, Post Graduate Program, Faculty of Social Science and Political Science University of Indonesia, Indonesia

\section{Wahyu Sardjono}

Information Systems Management Department, BINUS Graduate Program - Master of Information Systems Management, Bina Nusantara University, Jakarta, Indonesia

\begin{abstract}
This paper aims to review the situation of social protection for workers in the digital industry which implements a pattern of partnership with sharing economy systems, especially two-wheeled online transportation. This study examines the limitations of social protection according to the Asian Development Bank (ADB) which includes five elements, namely social insurance, social assistance, community protection with microschemes and area-based schemes, labor markets, and child protection. This study uses mixed methods with a qualitative main approach supported by a quantitative approach. The results show that there are some problems in social protection for workers in the informal sector, especially two-wheeled online transportation which is caused by a legal vacuum in the status of the partnership pattern so that it affected the welfare level of online transportation riders. Therefore, this study proposes a social protection model of informal workers in the digital era with a sharing economy system, which in its application will be supported by a fair partnership policy model so that it can provide social protection, because there are social security scheme initiatives for workers informal which requires contribution from each party to social security costs.
\end{abstract}

Key words: Digital Industry; Online Transportation; Social Protection; Sharing Economy

Cite this Article: Endang Yuniastuti, Bambang Shergi Laksmono, Wahyu Sardjono, Initiating Social Protection Scheme in the Sharing Economy Industry (Case of Indonesia Go-Jek Rider), International Journal of Management, 10 (5), 2019, pp. 128-144.

http://iaeme.com/Home/issue/IJM?Volume $=10 \&$ Issue $=5$ 


\section{INTRODUCTION}

Nowadays public transportation facilities are important for the community because they can make it easier to carry out daily activities for their survival. Of the many types of transportation in Indonesia, two-wheeled transportation (motorbike) is preferred by the general public, especially in big cities like Jakarta, because it avoids congestion. Besides that two-wheeled vehicles can be used as a livelihood that we know as ojek. The longer ojek starts to develop, then it is supported by technology that is growing rapidly and many intelligent people can find new things to create jobs for the community (Citradewi \& Soebandono, 2017). PT Go-Jek Indonesia was established in 2010 with 20 motorcycle taxi riders using the call center. PT. GoJek Indonesia was established by Nadiem Makarim and Michaelangelo Moran. The company is engaged in transportation services as an intermediary that connects motorcycle taxi riders with customers. PT. Go-Jek is a social-minded technology company that aims to improve the welfare of workers in various informal sectors in Indonesia (www.go-jek.com).

The presence of Go-Jek as online transportation service provider is proved to have a positive impact on the country's economy. This can be seen from the research held by the Demographic Institute of Faculty of Economics and Business, University of Indonesia (LD FEB UI) which conducted in October 2017 - December 2017 involving more than 7.500 respondents with 3.315 two-wheeled riders, 3.465 Go-Jek service users and 806 MSME partners spreaded in nine regions, namely Balikpapan, Bandung, Greater Jakarta, Yogyakarta, Makassar, Medan, Palembang, Bali and Surabaya.

In research on the direct and indirect social and economic impacts generated by Go-Jek on the Indonesian economy, it was proved that the company was able to contribute Rp. 9.9 trillion per year to the national economy which $\mathrm{Rp} 8.2$ trillion per year from online transportation partners and coupled with $\mathrm{Rp} 1.7$ trillion in annual income generated through partners of Micro, Small and Medium Enterprises (MSMEs) (kumparan.com, Thursday, March 22, 2018).

Comparing to their income before joining Go-Jek, it was estimated that there was a difference in monthly income that enters the national economy of Rp 682,6 billion. While the additional income generated by the MSME partners of Gojek was estimated to reach Rp. 138, 6 billion per month. This also supports MSME players to go-online and open direct access to consumers and increase business. In that research, it was revealed that the average income of full-time motorbike partner of Go-Jek reached Rp 3, 48 million per month, or 1, 25 times greater than the average city minimum wage in 9 survey areas of $\mathrm{Rp} 2.8$ million. In addition, LD FEB UI also revealed that there was an increase in motorbike partner income by 44 percent, both those who had previously worked and those who were unemployed. But along with the increase in income, the average expenses of partners also increased by 31 percent (kumparan com, Thursday, March 22, 2018).

However, although the presence of online transportation is considered beneficial for the welfare of the community, its presence also cause new problems for the people and the Indonesian government. One problem that arises due to the presence of online transportation is the issue of decent social protection for online transportation workers. BPJS Employment (Manpower Social Security Organizing Agency) as a social security organizing body appointed by the Government to implement social security programs for workers in Indonesia, classifying two-wheeled on line transportation riders as Informal or Wage Recipient (Wage) worker groups. In accordance with the prevailing laws and regulations, the payment of membership contributions to BPJS Employment for Non-Wage Workers (BPU) must be paid independently by the workers themselves. The BPJS Employment Program includes (1) Work Accident Guarantee Program, (2) Death Assurance Program, and (3) Old Age Insurance Program. But in reality, some informal workers in Indonesia have not made Employment Social Security as a priority in their lives, even though the environment of informal workers is full of risks. This is 
due to several factors, including (1) limited knowledge related to social security benefits, (2) lack of awareness of the importance of social security (3) limited income for everyday life.

Therefore, research on the welfare and social protection of Go-Jek riders as informal sector workers needs to be done. This is because the research on the impact of welfare from the digital industry in Indonesia is still very little or even non-existent. Various writings and general articles about the benefits and work relations between the riders and the Go-Jek Company have been written by various observers. These writings have been useful for understanding the outline or big picture, however, there has not been a systematic study to see the condition of welfare of online transportation workers and their social protection has not been widely adopted so that this research becomes important to discuss.

\section{METHODS OF RESEARCH}

This research is a mixed methods study by combining two forms of approaches in research, namely qualitative and quantitative. The main approach of this study is a qualitative approach supported by a quantitative approach. Then this study is categorized as a type of explanative and descriptive research. This type of research is to describe the conditions of welfare and social protection of Go-Jek online transportation riders in Bandar Lampung and Jakarta as a whole and comprehensively. In addition, the research also seeks to explore the reasons and causes of social protection so needed for new types of informal sector workers in the digital industry.

The informants from this study were determined through a Purposive Sampling technique by determining the criteria of the informants needed in the study consisting of key informants, main informants, and additional informants. This qualitative research began in June 2015, preceded by preeliminary research, followed by FGD in November 2017, then the field research ended in July 2018. The researcher used several methods of data collection as follows: 1) Observation, 2) Interview, 3) Library Study, 4) Documentation, 5) Focus Group Discussion (FGD) or Focus Group Discussions, and 6) Questionnaires.

To complement and strengthen the data, researchers also distributed questionnaires to 102 Go-Jek riders in Bandar Lampung and 102 Go-Jek riders in Jakarta. The average education level of Go-Jek riders in Bandar Lampung and Jakarta is high school, followed by Academies/Colleges, Middle Schools, and Elementary Schools. In terms of age, Go-Jek riders in Bandar Lampung are dominated by riders aged 25-35 years, while for Go-Jek riders Jakarta are dominated by riders over the age of 35 .

The reasons for choosing the Bandar Lampung and Jakarta regions for the location of this study are for several reasons: (1) trying to see the development of consumers in 2 settings to provide an overview of social protection in the development of a growing market. Jakarta represents major cities in Indonesia and Go-Jek first presented in Jakarta. Bandar Lampung is a city outside of Java and Go-Jek presented in Bandar Lampung at the end of March 2017, (2) based on literature studies and observations, researchers see the activeness of Go-Jek riders in Bandar Lampung and Jakarta in social activities as well as in advocacy activities to voice out opinions to achieve prosperity. With this growth, research needs to be done to see an overview of the conditions of welfare and social protection, especially for Go-Jek riders by paying attention to the variable differences in social demographic conditions in the two regions.

\section{LITERATURE REVIEW}

\section{The Concept of Industrial Revolution 4.0}

The concept of industrial revolution 4.0 is a concept first introduced by Professor Klaus Schwab, the German economist and initiator of the World Economic Forum (WEF) through his book The Fourth Industrial Revolution, stating that industrial revolution 4.0 can fundamentally 
change the way we live, work and connect with another. Industrial Revolution 4.0 can be called an era of competition that demands life skills so that we are able to easily adjust the needs of the times.

Alvin Toffler through his book Future Shock maps the future. Future mapping is a process that will show the opportunities available to an individual, an organization, industry, market, nation, even civilization. Future maps show a combination of emerging forces that will shape the conditions of industries in the future.

\section{The concept of a Sharing Economy}

Benita Matofska defines the sharing economy as a socio-economic ecosystem built from sharing resources both human and goods. It includes sharing about the creation, production, distribution, trade and consumption of goods and services by different people and organizations. There are 10 components in building this sharing economy: Humans, production, systems and values, distribution, planets, strength, the law of sharing, communication, culture and sustainability. The most important of them is: economic sharing emphasizes the principle of the realization of harmony that is synergized between humans and also with nature. This is the main point (Matofska, 2016).

\section{The concept of social protection}

In the broadest sense, social protection can be defined as all initiatives carried out by the government, the private sector, and the community that aim to provide income or consumption transfers to the poor, protect vulnerable groups from livelihood risks and improve status and social rights of marginalized groups in a society (Suharto, et al, 2006). The existence of the digital economic era is currently challenging to create new opportunities for social protection systems in three dimensions, namely: 1) Inclusive for individuals involved in and outside the digital economy, 2) Providing coverage for marginalized populations such as migrants (legal) and people who work outside the formal economy (such as people in rural and remote areas in developing countries) who may or are not involved in the digital economy, 3) Provide social safety nets for people and dependents who participate in traditional labor markets and for those who move into the digital economy.

\section{Concept of Social Welfare}

James Midgley defines Social Welfare as a condition or condition of human life created when various social problems can be managed properly; when human needs can be fulfilled and when social opportunities can be maximized. In Indonesia, the definition of Social Welfare cannot be separated from what has been formulated in Law No. 6 of 1974 concerning the Main Provisions of Social Welfare article 2 paragraph 1: "Social Welfare is a system of life and livelihood of material and spiritual social which is covered by a sense of safety, morality, and inner and outer peace, which allows for every citizen to make efforts to fulfill the best physical, spiritual and social needs for themselves, their families, and the community by upholding human rights and human obligations in accordance with the Pancasila "(Adi, 2005). 


\section{Theoretical Framework}

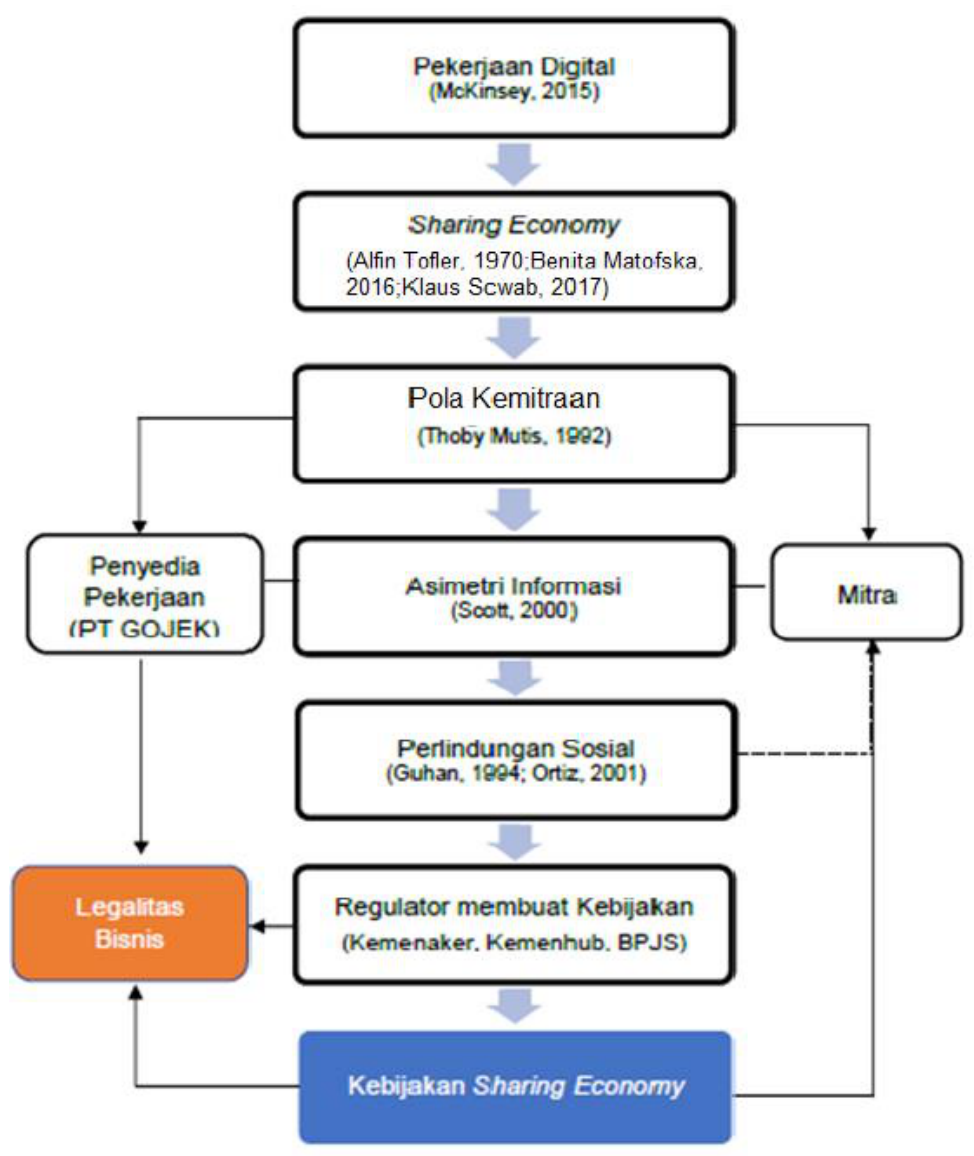

Figure 1. Theoretical Framework of Research

Source: Processed by Researchers, 2018

\section{FINDINGS}

From the results of the field findings through the Focus Droup Discussion (FGD), the Go-Jek riders revealed that they were the ones who were harmed by the partnership pattern implemented by PT. Go-Jek Indonesia. Because the company is often arbitrary in making new regulations that turn out to be detrimental to riders and decision-making process that not through deliberations with Go-Jek riders. As a result, riders feel being exploited by the company. This was revealed by Pak SM, one of the Go-Jek riders in Jakarta, "What we are talking about is exploitation, clear. We talked about that before. Just stay here alone. That's exploitation" (Pak SM, FGD, 2017). Besides Pak SM, Mr. RSD also felt the same thing, PT. Go-Jek has violated regulations and exploited riders. "So PT. This Go-Jek doesn't treat arbitrarily. Don't exploit humans. Well, that shouldn't be, it will violate the rules if you exploit it "(Mr. RSD, FGD, 2017).

Rates that often change and without prior notice to Go-Jek riders cause the riders to experience a significant reduction in income. The tariff war between applications causes online transportation companies to compete to reduce tariffs or give discounts to consumers. As a result, the income of Go-Jek riders will decrease and experience uncertainty every day.

Based on the results of the questionnaire to 102 Go-Jek riders in Bandar Lampung, it was found an interesting fact that the average gross income per month for Go-Jek riders is only around $\mathrm{Rp} 1.000 .000$ - Rp 2.000.000. A total of 57 respondents revealed that the monthly gross 
income is only around $\mathrm{Rp} 1.000 .000$ - Rp 2.000.000. Meanwhile, 42 other respondents had a gross income of around $\mathrm{Rp} 2.000 .000$ - Rp 3.000.000. And only 3 respondents had gross income more than $\mathrm{Rp} 3.000 .000$.

When compared with the average gross income of Go-Jek riders in Jakarta, it was found that 59 respondents had the average gross income in the range of $\mathrm{Rp} 2.000 .000$ - Rp 3.000.000. While the number of riders with a gross income of Rp 1.000.000 - Rp. 2.000 .000 is 43 respondents. And surprisingly, none of the respondents in Jakarta stated that the average gross

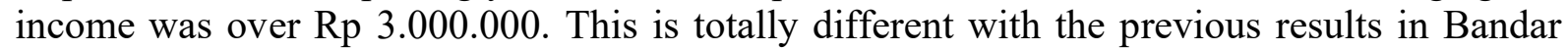
Lampung, where there are at least 3 people who have gross income above Rp 3.000.000. This can be seen in the following graph.

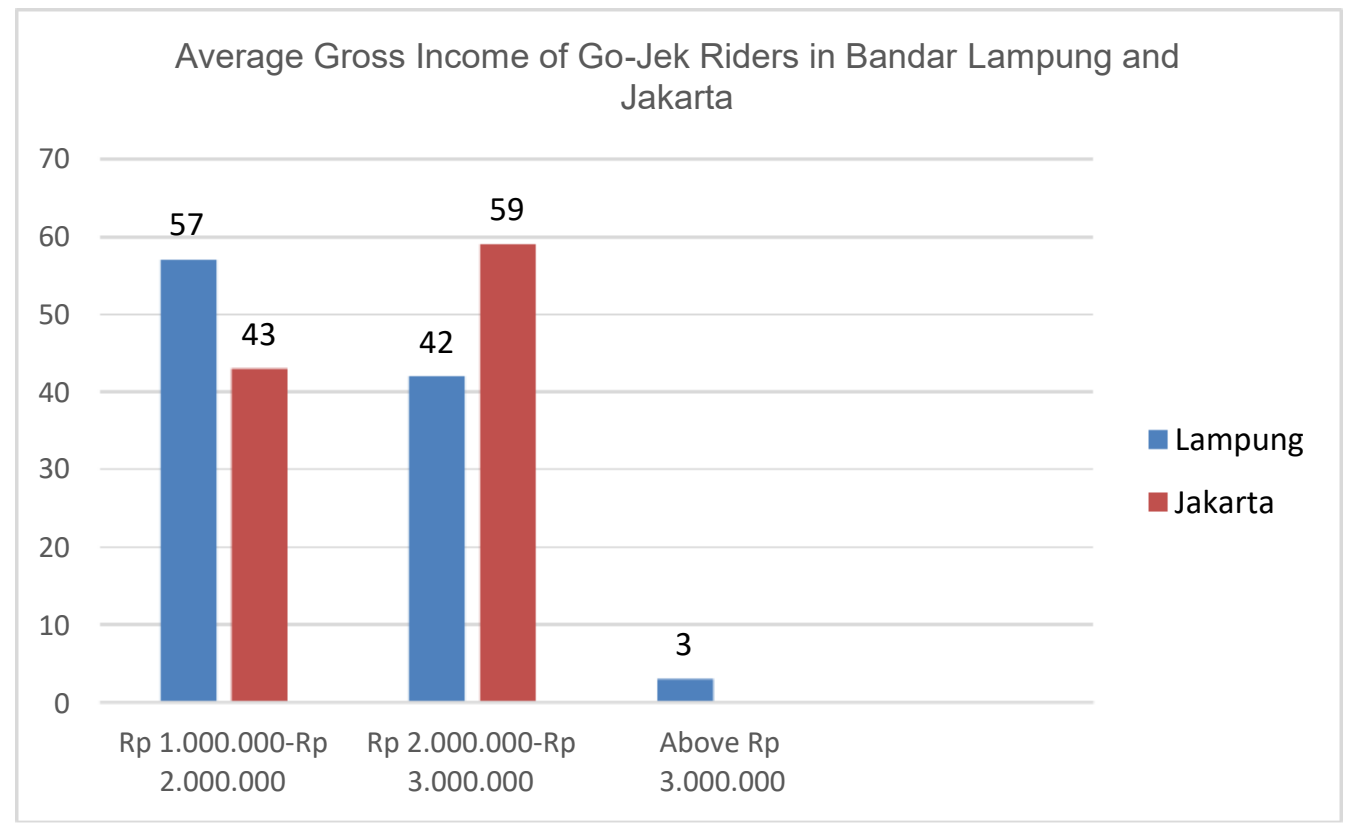

Source: Processed Research Questionnaire (2018)

From the gross income, if it is reduced by operational costs, the net income obtained by the rider is much lower. There are 76 of 102 respondents in Bandar Lampung claimed to only get Rp. 1.000 .000 - Rp. 2.000.000 net income per month. Meanwhile, 23 respondents received a net income about $\mathrm{Rp} 2.000 .000$ - Rp 3.000.000. And only 3 respondents received net income above Rp. 3.000.000. It shows that the biggest net income of Gojek riders is only around Rp 1.000.000 - Rp. 2.000 .000 per month.

Then when compared to the average net income of Go-Jek riders in Jakarta, it was found that 53 respondents had a net income about Rp 1.000.000 - Rp. 2.000.000. While 49 others answered that their average net income was around Rp. 2.000.000 - Rp. 3.000.000. Overall, it can be concluded that the average net income of Go-Jek riders in Bandar Lampung which in the range of Rp. 1.000.000 - Rp. 2.000 .000 is more than the Go-Jek riders in Jakarta. However, from the results of the Jakarta's questionnaires, there were no riders who had a net income of more than Rp. 3.000.000. This is different from the results in Bandar Lampung where there were 3 respondents who had net income above Rp. 3.000.000. The amount of net income earned by the Go-Jek riders can be seen in the graph below. 
Wahyu Sardjono, Initiating Social Protection Scheme in the Sharing Economy Industry (Case of Indonesia Go-Jek Rider)

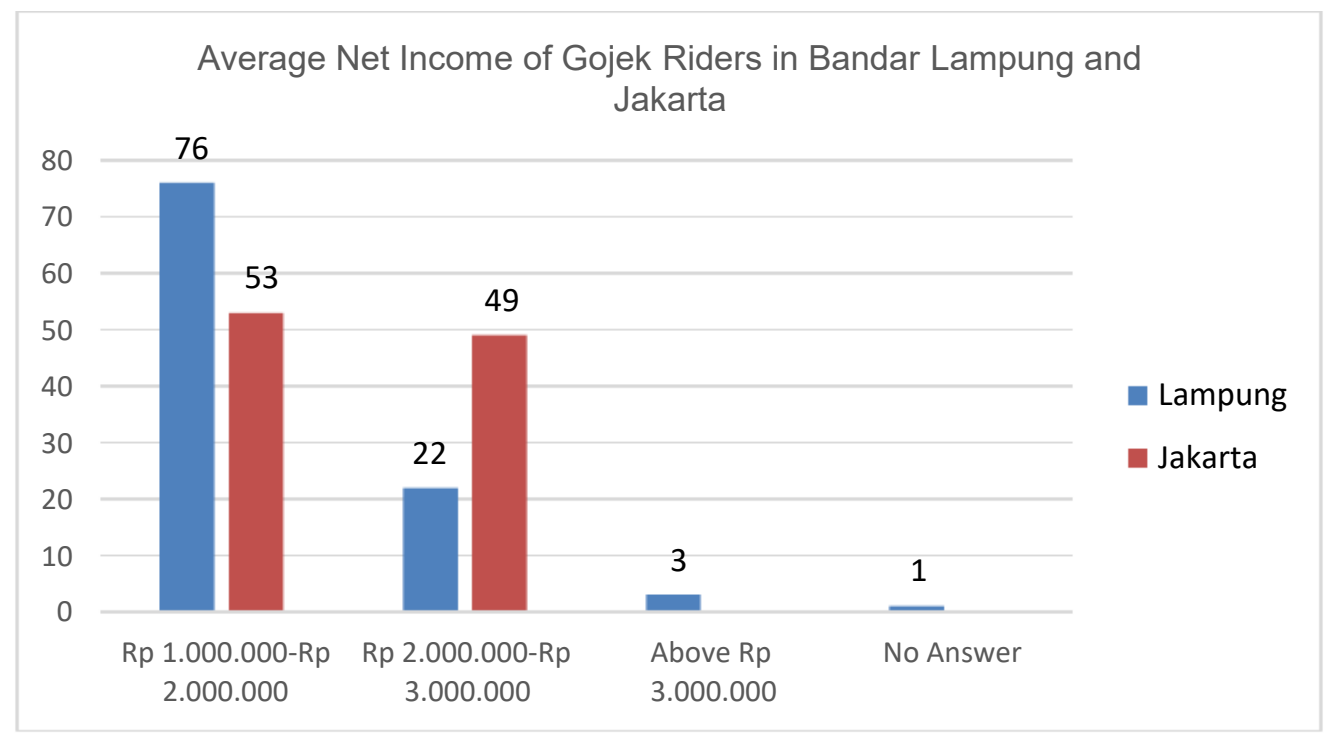

Source: Processed Research Questionnaire (2018)

Then, in the average amount of monthly expenses issues, it was found that most of respondents in Bandar Lampung spent $\mathrm{Rp} 1.000 .000$ - Rp 2.000.000 each month. The number of respondents who have an average monthly expenses about $\mathrm{Rp} 1.000 .000$ - Rp 2.000.000 are 53 respondents. And 32 others had an average monthly expenses around Rp 2.000.000 - Rp 3.000.000. Then the remaining 17 respondents had an average monthly expenses more than $\mathrm{Rp}$ 3.000.000.

When we compare with the average monthly expenses of Go-Jek riders in Jakarta, There are 34 of 102 respondents in Jakarta spent Rp 1.000.000 - Rp 2.000.000 each month, 63 respondents spent $\mathrm{Rp} 2.000 .000$ - Rp 3.000.000 each month, and 5 others spent over $\mathrm{Rp}$ 3.000.000 in every single month. It was very interesting because the riders who had monthly expenses about $\mathrm{Rp} \mathrm{2.000.000} \mathrm{and} \mathrm{above} \mathrm{is} \mathrm{more} \mathrm{than} \mathrm{the} \mathrm{riders} \mathrm{who} \mathrm{had} \mathrm{monthly} \mathrm{expenses}$ under Rp 2.000.000. The comparison can be seen in the following graph below.

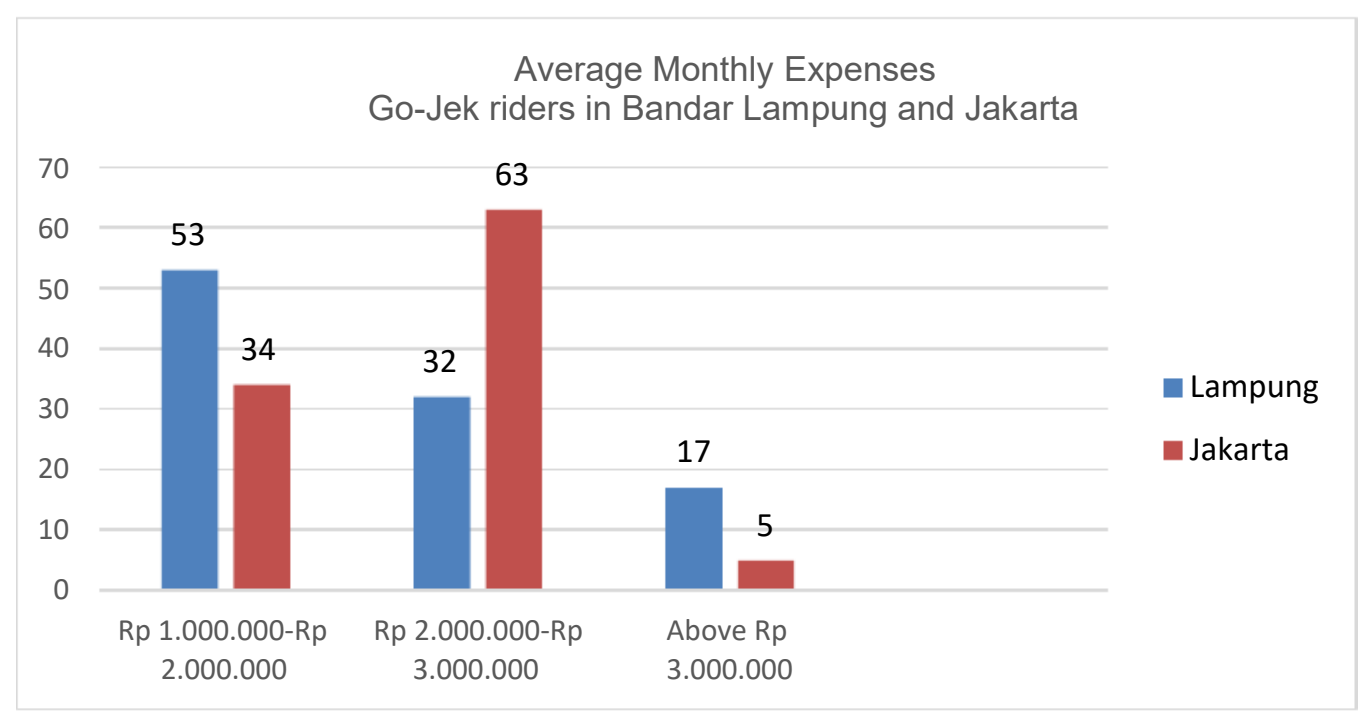

Source: Processed Research Questionnaire (2018)

Then when it was viewed from the average gross income and net income of Gojek riders in Bandar Lampung, it can be seen that the income does not meet the average monthly expenses. From the previous net income diagram, it can be seen that the average amount of Go-Jek riders' 
net income is $\mathrm{Rp} 1.000 .000$ - $\mathrm{Rp} 2.000 .000$. This shows that the income is not enough to fulfill their daily needs, especially for Go-Jek riders who have quite a lot of family dependents and do not have other jobs besides being Go-Jek riders.

Meanwhile, for Go-Jek riders in Jakarta, it can be concluded that the net income is not sufficient to meet the expenses needs of each month. This can be seen from the highest amount of net income for Go-Jek riders in Jakarta is in the range of Rp 1.000.000 - Rp 2.000.000. But most monthly expenses are in the range of $\mathrm{Rp} 2.000 .000$ - $\mathrm{Rp} 3.000 .000$. When it is compared from the results of questionnaire in Bandar Lampung and Jakarta, it turned out that the expenses of Gojek riders in Jakarta was much greater than that of the Gojek riders in Bandar Lampung. The factors that might be the cause of this difference are the prices of basic commodities and other different needs in Bandar Lampung and Jakarta, where the price of needs in Jakarta is higher so that the expenses is even greater. This condition is further complicated by the large number of Go-Jek riders both in Jakarta and Bandar Lampung that use Gojek as their main livelihood.

From 102 respondents in Bandar Lampung, it was found that 87 Go-Jek riders only had jobs as Go-Jek riders or did not have other jobs. Only 15 people have other jobs besides being a GoJek rider. When compared to Go-Jek riders in Jakarta, the number of Go-Jek riders in Jakarta who have other businesses or jobs besides as Go-Jek riders is more than that of Go-Jek riders in Bandar Lampung. A total of 28 riders have other businesses or jobs outside of work as riders of Go-Jek. And around 74 people do not have other businesses or jobs. This can be seen in the following graph below.

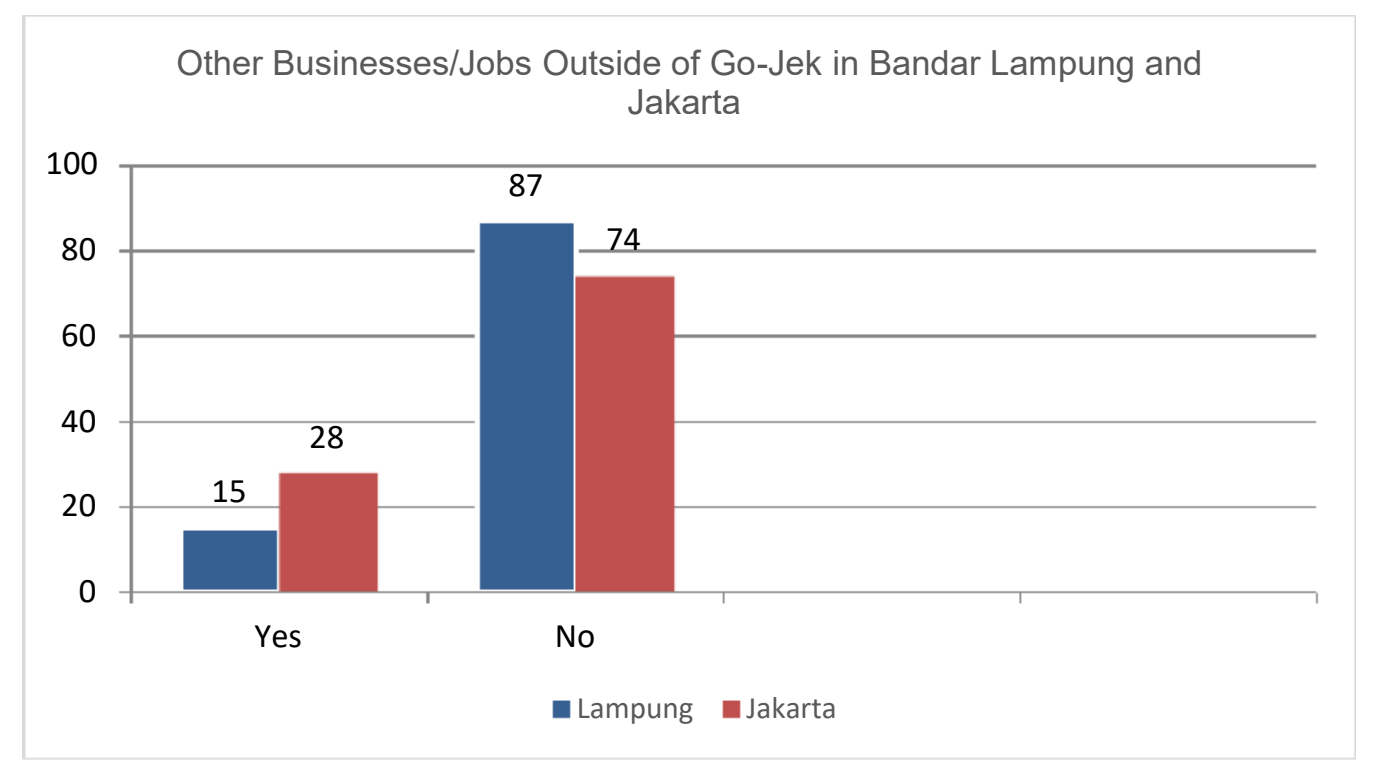

Source: Processed Research Questionnaire (2018)

But even though the number of Go-Jek riders in Jakarta who have other businesses/jobs outside of Go-Jek riders is more than that of Go-Jek riders in Bandar Lampung, the number of Go-Jek riders who do not have other businesses/jobs in both cities is more than those who have other businesses/jobs. It shows that working as a Go-Jek rider is the main source of livelihood for most Go-Jek riders.

Ironically, in the midst of dependence on livelihoods as a Go-Jek rider, the average Go-Jek rider has a large number of family dependents. About 33 respondents have 1 to 2 dependents, 59 respondents have 3 to 5 dependents, 7 respondents have more than 5 dependents, and 3 respondents did not answer. Similar to the results of the questionnaire on the Go-Jek rider in Bandar Lampung, in Jakarta, the number of dependents of the most family members was 3-5, 
namely 43 respondents. Then 36 respondents have 1-2 family dependents, 2 respondents have family dependents more than 5 people, and 21 respondents did not answer. This can be seen in the following graph below.

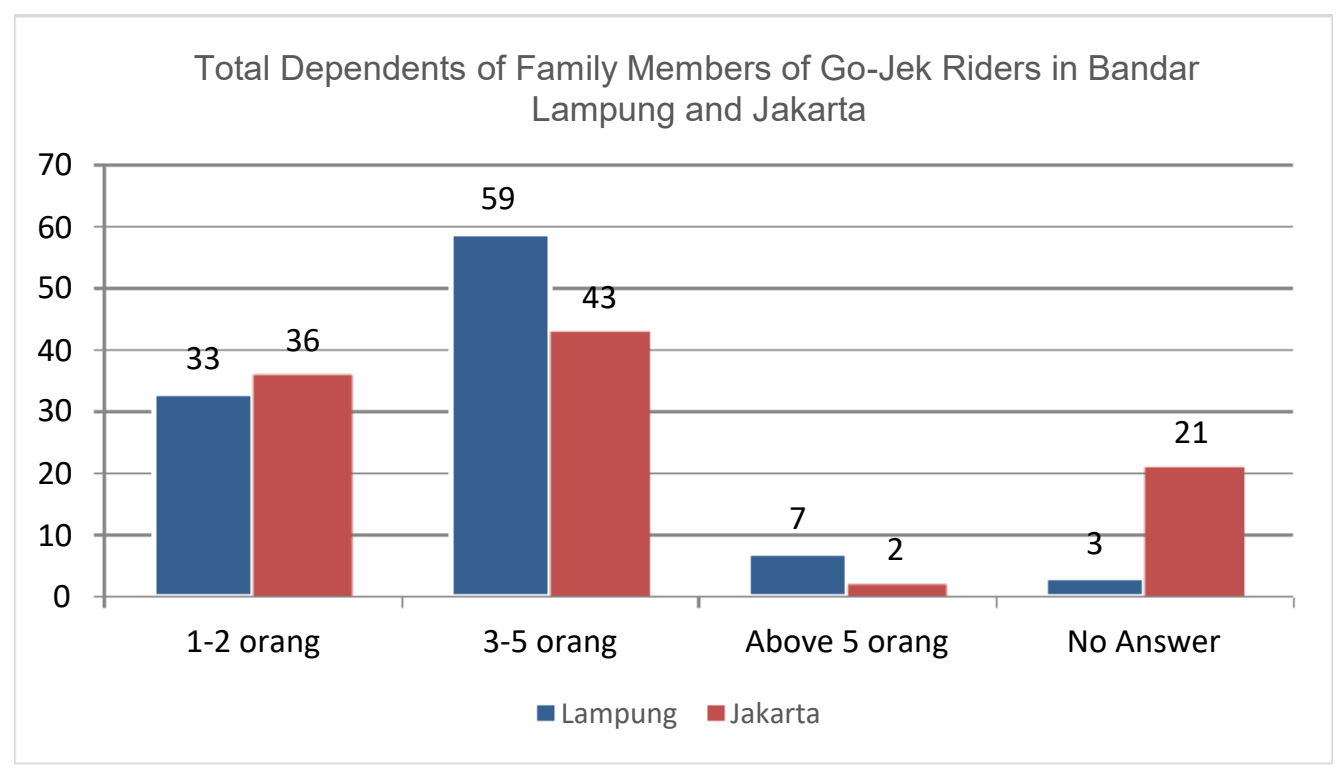

Source: Processed Research Questionnaire (2018)

Not only about the issue of fare determination, did the riders also not get proper facilities. The free facilities obtained by Go-Jek rider's only masks and headgear (helmet). Like Mr. AR's confession, "Free masks and headgear. We took both with much efforts."(Pak AR, FGD, 2017).

In accordance with the findings in the field, in the media coverage it was explained that the Go-Jek riders did not get a salary from the application company because their status in the work agreement was as a partner with a profit sharing system of 20:80. How much the rider's income depends on how many passengers can be delivered? The order to take passengers also did not come from the company, but from passengers and of course the willingness of the Gojek riders. In this condition, it appears that there is no element of work relations in the relationship between the rider and the application provider company. Thus it is concluded that there is no working relationship between the rider and the application company. Because there is no working relationship, the rider is not entitled to claim the rights normally received by workers in general such as overtime pay, social security and severance pay if their cooperation relationship ends.

Often the rider's performance percentage does not increase even though they have completed the order. Conversely, if the order is canceled, both by the rider and the customer, their performance percentage falls dramatically. Information obtained from several online riders said that the performance if it rises is difficult, but it's easy to get off. When the rider tries to report this technical problem to the company, they get a standard answer, which is set by the system. Bonuses as incentives are supported by the imposition of suspension as a means of disciplining riders. The suspension system is the main strategy to force riders to follow the rules. Riders cannot reject or cancel too many orders. The risk, riders can be subject to sanctions ranging from temporary suspension to breaking partners.

This is reinforced by the results of the questionnaire to the Go-Jek riders in Bandar Lampung where it was found that the number of Go-Jek riders who had received bonuses was fewer than the Go-Jek riders who had never received a bonus. Of the 102 respondents, 46 had received bonuses from PT. Go-jek, while 56 other people have never received a bonus from PT. Go-Jek. This further strengthens the statement of the Go-Jek riders in the FGD stating that they 
have difficulty getting the current bonus because many conditions and the high points that must be achieved by the riders.

Not much different from the results of the questionnaire on Bandar Lampung's riders, the results of the questionnaire on Gojek riders in Jakarta also showed that most riders had received a bonus. Of the 102 respondents, 39 people have never received a bonus, while 63 people have received bonuses. In addition to the increasingly difficult bonuses, it turns out that Go-Jek payments via Go-Pay also cause problems for Go-Jek riders because they suffered losses due to discounts (fees) charged to consumers so that their income is reduced.

"Yes it's reduced, why? Because it got a discount earlier. We don't get a promo. No discount. For example, you have to pay for Rp 45.000, but because there is a discount so it becomes Rp 30.000. We become loss" (Pak AR, FGD, 2017).

Another problem felt by riders is the termination of unilateral partnership by the company without any clarity (suspend). Often the company decides on a sudden partnership relationship with the reason that there is a report from the consumer to Go-Jek or the consumer gives a low value to the rider. Without explanation and confirmation, the Go-Jek rider will be dismissed by PT. Go-Jek. This is also the injustice felt by Gojek riders. As a result, they immediately lost their livelihood as Gojek riders. The following are excerpts of interviews with Go-Jek partners:

"Even though I don't say anything. What the hell, a customer give me a 1 star. I was suspended by Gojek. But we don't know why. Maybe the customer hit the hole on the road, we don't know. She became offended but didn't comment. But when we just arrived, she gave me 1 star and also commented, 'the rider is careless, doesn't pay attention to safety'. Then, I directly suspended by Gojek" (Pak AR, FGD, 2017).

In line with the field findings from the FGD, the reasons for this suspension were different for each Go-Jek rider. But through the results of the questionnaire, it can be stated that the number of riders who have experienced suspensions is indeed quite a lot. In accordance with the rules of PT. Go-Jek, indeed the worker partner has the right to defend when being "suspended", and if the reason for the defense can be accounted for, then the worker partner can work again. But for the process, it requires an effort and a long and tiring time.

\section{DISCUSSIONS}

The results of research at the Communication Study Center of University of Indonesia on May 2017 stated that $77 \%$ of full-time riders earn above the national UMP average of Rp 1.997.819 (BPS, 2016). And full-time riders earn more than part-time riders. This is important because the majority of riders have many dependents. Then the research of the Demographic Institute of University of Indonesia on the Impact of Go-Jek to the Indonesian Economy stated that GoJek increased the income and expenses of motorbike partners and family welfare. The survey revealed that the average monthly income of two-wheeled riders partners was higher than the average District Minimum Wage (UMK) in 9 survey areas. However, this results were different from the survey conducted by researcher until July 2018 in 2 research locations, namely Bandar Lampung and Jakarta. The survey results of the researchers found that the income of the GoJek riders declined below the Provincial Minimum Wage. Provincial Minimum Wage of Lampung for 2018 was $\mathrm{Rp} 2.074 .673,27$ and $\mathrm{Rp} 3.648 .035,82$ for DKI Province. While the results of the survey of researchers on July 2018 stated that the average income of Go-Jek riders in Bandar Lampung Province was Rp. 1.000.000 - Rp 2.000.000 and in DKI Jakarta Province was $\mathrm{Rp} 2.000 .000$ - Rp 3.000.000. Officially the central government through the Ministry of Manpower (Kemnaker) has set a 2019 provincial minimum wage increase (UMP) of 8.03 percent. If referring to the determination of national UMP increases, then DKI Jakarta will be the region that has the highest UMP namely Rp 3.940.972. While the Provincial UMP of 
Lampung in 2019 amount to $\mathrm{Rp} 2.241 .269$. But based on the survey conducted by researcher, the monthly income currently received by riders is under the UMP.

Decreasing income of two-wheeled online transportation riders that have an impact on the level of welfare can be understood if we look at the policies of PT. Go-Jek which continue to reduce fares unilaterally. In the partnership agreement agreed upon by the partner parties before registering as a partner, indeed there is a clause in Item 2 of the Cooperation Relations stating that "AKAB, as the owner of the Go-Jek Application, can change or add requirements from time to time ". If we see from the existing Cooperation Agreement, actually there is an agreement here between 3 parties, namely PT Go-jek, PT AKAB and Go-Jek partners. PT GoJek Indonesia, PT AKAB and Partners are collaborative partners where each is an independent legal subject. PT Go-Jek Indonesia is a company that manages collaboration with partners and PT AKAB is the owner and operator of the Go-Jek application that is used by partners.

At the beginning of Go-Jek's first appearance in Jakarta and Bandar Lampung, indeed the riders' income were above the Provincial Minimum Wage (UMP) so that it affected the level of welfare of Go-Jek partners. There were even some formal workers who left their formal jobs and turned to become Go-Jek riders. At the beginning of the application of the Go-Jek application, the guaranteed rate applied $\mathrm{Rp} 13.000$ for $0-5 \mathrm{Km}$ - then the next $\mathrm{Km}$ was $\mathrm{Rp}$. 4,000. Then there was a unilateral reduction in the amount of $\mathrm{Rp} 10.500$ for $0-7 \mathrm{Km}$ - while the next per Km was Rp 3.000. Even at this time the rates has declined to Rp 8.000 for $0-8$ $\mathrm{Km}$, where the next fare per Km was Rp 1.600, while there was an increase of fuel oil cost (BBM). Even though Premium did not rise, only Pertalite and Pertamax, but the fact is that Premium is difficult to find because not all gas stations sell Premium. So the income of the GoJek rider is inversely proportional to the increasing costs and needs. In addition, the number of Go-Jek riders also increase so that the income of Go-Jek partners declines due to intense competition due to high supply. With the current low income conditions, the Go-Jek riders find it difficult to fulfill their basic needs, especially for Go-Jek riders who have quite a lot of dependants.

The biggest problem for informal workers such as two-wheeled online transportation riders is the lack of a social security system. Informal workers usually have lower incomes than formal workers, so they cannot buy private insurance and pensions and also do not pay taxes to access government interests. Therefore, they usually have little or no protection by labor standards (such as minimum wages) and rights (such as sick leave, health insurance, or unemployment insurance), and they also do not have workers organizations or representation. They are usually excluded from social protection against work risks or uncertainties (such as late payments and work safety) and also do not have arrangements to address general contingencies about illness, disability, property loss, and death, while types of work in the informal sector are often at high risk of environment that is dangerous, precarious, and vulnerable (Setiyono, 2018).

The lack of strong legal rules regarding the employment social security system for informal workers can be seen from the level of participation of informal workers in the Social Security Program (Saswono, Thabrany, et al, 2013). The BPS data in February 2018 stated that the number of informal workers was 73.98 million people, while according to the data on membership of BPJS Employment in August 2018, the participation of active non-recipient wages (informal) was 1,822,587 people. Inadequate regulations, legal uncertainty, and partnership patterns of work that are considered unfair in the digital economic era make it difficult to encourage two-wheeled online transportation riders as informal workers to make efforts to meet their physical, spiritual and social needs for themselves and their families. Based on field findings for Go-Jek riders in Bandar Lampung and Jakarta that were carried out until July 2018, two-wheeled online transportation riders cannot obtain optimal welfare conditions, because actual income is not enough for their actual needs. This is due to several factors, 
including (1) due to the absence of quota restrictions on the acceptance of Go-Jek riders, even though the number of consumers of Go-Jek users is not increasing. So that the Go-Jek riders find it harder to get orders from consumers. (2) the occurrence of fare wars among application companies that provide online transportation services such as Grab, has resulted in a massive discount program to capture consumers. In these conditions, of course the losers are the Go-Jek riders, because the income as partners is a small portion. But they continue to be online transportation riders because it is difficult to find new jobs and this job is their main source of their livelihood.

In the existing labor regulations, it is difficult for the government to intervene in the informal sector to include its workforce in the Workers' Social Security program (Jamsostek). Although in regulation, the Ministry of Manpower and Transmigration has regulated this issue in the Minister of Manpower and Transmigration Regulation Number 24 / MEN / VII / 2006 concerning Guidelines for Implementing Workers' Social Security Programs for Workers who Work Out of Employment, but this regulation is only an appeal without any full obligation for the informal sector to run it (Saswono, Thabrany, et al, 2013).

For the government, a form of guarantee for workers' protection continues to be sought through BPJS that every worker / laborer is required to become a participant in the BPJS program by being registered by the company where they work, but very large numbers of workers outside the employment relationship need to be considered their social activities are not registered and paid directly by the company. However, it must be understood that online transportation riders are divided into 2 groups, namely people who work full time as online transport riders, and people who work freelance or have other jobs besides as online transportation riders. If they have another job then they may have social security.

As contained in Law Number 24 of 2011 concerning the Social Security Organizing Agency, health insurance, work accident insurance, old age security, pension insurance, and life insurance are part of the social security system in the employment sector because these protections are part of the rights humanity. The important thing in the digital economy era is the protection of workers, namely participation in social security both health and employment with an easy process and assistance with payment of monthly social security contributions.

Based on the results of the FGD on December 22, 2017, observers of employment Prof. Dr. Payaman Simanjuntak said that there were 3 things that social security wanted by workers from the State, namely health insurance (BPJS Health), social security carried out by the BPJS Employment, as well as guarantees of security and continuity of income. The Labor Law needs to be reviewed in depth in the current information era. Social security for online transportation riders carried out BPJS Employment from November 2016 in the form of Work Accident Insurance (JKK) and Death Assurance (JKm). But not all online riders become participants, because they are not mandatory. Each participant must pay for their own BPJS Employment contributions of Rp. 16.800 / month.

So far, PT. Go-Jek Indonesia actually has tried to provide social protection such as insurance in the form of on trip coverage. But this only applies on the road as long as the rider takes the passengers to their destination. The rider does not get protection in the event of an accident in the off trip condition, which is a condition where the rider is not or is taking or picking up passengers who have ordered through the application. The MoU between BPJS Employment and PT Go-Jek Indonesia does exist, but the content is only an agreement that PT. Go-Jek is obliged to help provide appeal to motoring partners through its application features in order to take part in the BPJS Employment program, but membership financing remains an obligation of motoring partners.

From the results of the discussions during the FGD, it was concluded that online transportation riders have the right to protection and social security, because work on highways 
is risky, and social security contributions should be shared (PT Go-Jek Indonesia and its partners). At present there is no definite pattern of social protection for new types of informal workers, especially two-wheeled online transportation riders.

Two-wheeled online transportation riders, especially Go-Jek riders, need government intervention. Although the cooperation agreement that they agreed on was a partnership agreement which was a private area of the partnering party. However, the Go-Jek partners (riders) are weak parties who really need jobs, so they don't have a good bargaining position. Although until now there is no regulation that states that two-wheeled vehicles are public transportation, in reality two-wheeled vehicles operate freely on the highway as public transportation. Besides that, there are no regulations governing partnership agreements with economic sharing systems. So that no institution or agency can control the partnership pattern applied. However, building partnerships must meet several requirements, including the existence of equality, the principle of mutualism (mutual benefit), and the existence of openness or trust relationship.

Every citizen has the right to get social security/protection so that their lives are above the limits of the feasibility of living in prosperity and not afraid to face disruption in life. The limits of life worthiness are principally related to the adequacy of five basic needs, namely: clothing, food, shelter, health, and education. This means that every citizen must try to fulfill their needs, but they get guarantees and protection when they cannot meet their basic needs personally (Setiyono, 2018).

After going through various discussions, in-depth interviews, FGDs, and literature studies, the authors formulated a social protection model for informal two-wheeled online transportation workers in the digital era as follows:

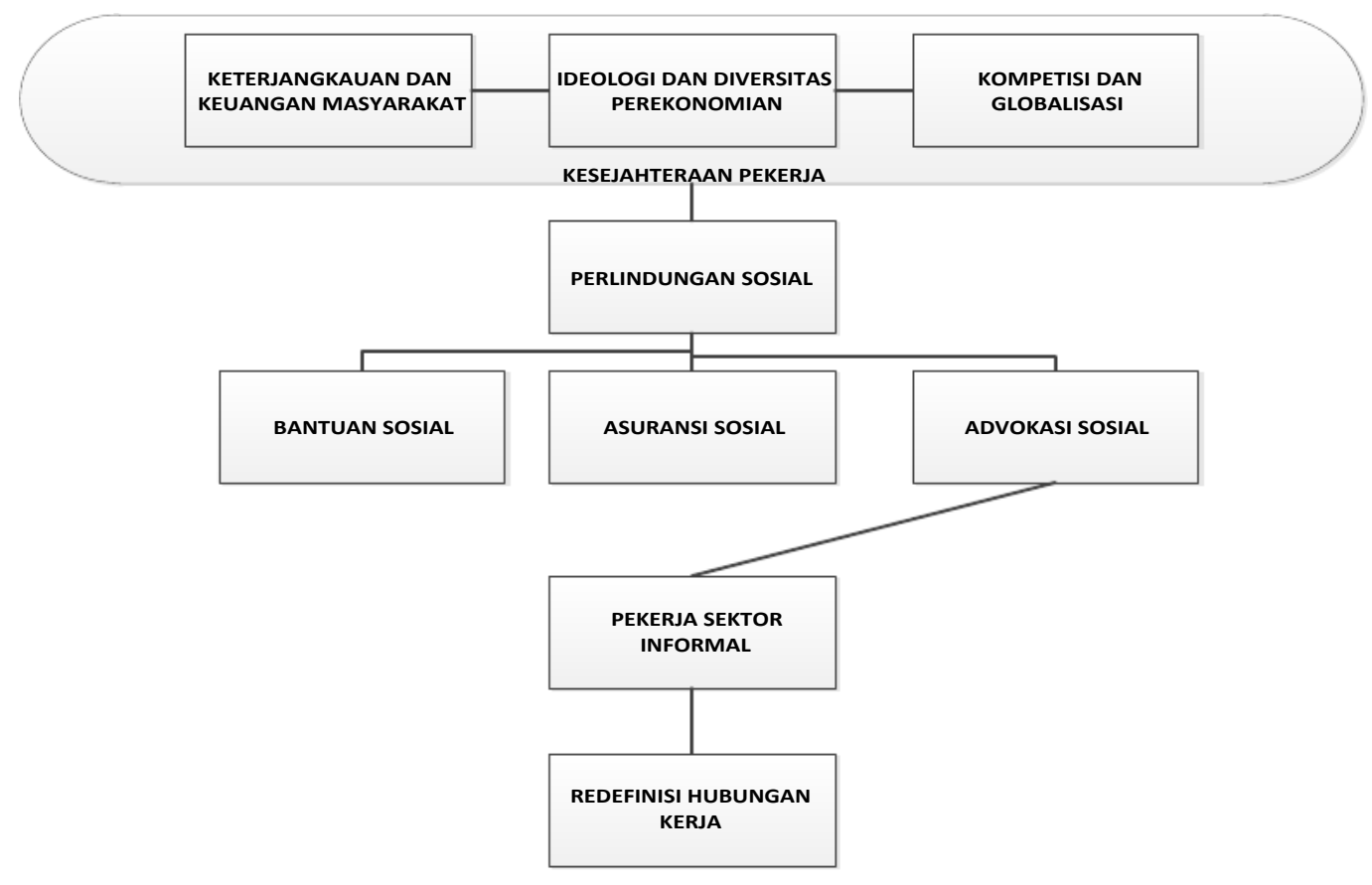

Figure 2. Social Protection for Informal Sector Workers

Source: Processed by Researchers (2018)

Viewing at the concept of a welfare state, even though Indonesia applies a minimal welfare state model, social protection remains a citizen right and obligations that must be fulfilled. However, because the current law in Indonesia has not clearly regulated work patterns and social protection for online transportation workers, it is necessary to change regulations by the 
government as a regulator. Therefore, a special intervention from the government is needed to regulate online transportation in Indonesia so that the workers get proper welfare. This intervention must be able to provide legal certainty in the pattern of partnership and social protection agreements so as to improve the welfare of two-wheeled online transportation workers in the digital industry era with a sharing economy system.

In the social protection model proposed by this author, workers' welfare is influenced by three factors, namely (1) affordability and public finance, (2) ideology and economic diversity, and (3) competition and globalization. If workers are able to deal with these three factors, the welfare of workers will increase. Conversely, if workers are unable to deal with these three factors, their welfare will decline.

In the context of online transportation workers, now the Go-Jek riders are in a position to be unable to deal with these three things. The cause was a legal vacuum and the status of the partnership agreement pattern which caused problems for the welfare of the Go-Jek riders. Therefore a pattern of social protection is needed that aims to provide protection for twowheeled online transportation workers.

Social protection is divided into three, namely (1) social insurance, (2) social assistance, and (3) social advocacy. For social insurance, cooperation is currently being sought between PT Gojek and BPJS Employment to provide protection in the form of worker insurance for Gojek riders as workers in other formal sectors. For social assistance, PT Go-Jek has sought to provide assistance to Go-Jek riders who have been hit by accidents, accidents, and died, where assistance is usually in the form of compensation. However, there is one aspect of social protection that is still lacking to date, namely social advocacy.

This social advocacy aims to fight for the legal certainty and work status of Go-Jek riders so that they can obtain appropriate social protection from the government and companies. This is related to the existence of a legal vacuum and unclear status of the partnership agreement applied by the company.

The 4.0 industrial revolution presents both opportunities and problems. One problem that might be caused by this revolution is the creation of unemployment which is influenced by the widening of economic inequality. Digitalization has shifted conventional work to digital work. The relationship between the employer and the recipient of employment, shifts from a permanent and static relationship, into a working relationship that is partnership or flexible partnership. In a relationship like this, workers can work for several different employers. In this work pattern, the workplace does not have to be monotonous in a place, and the time is also flexible. The era of digitalization has shifted the pattern of employment relations (permanent) into a pattern of partnership work (flexible), so that existing labor regulations have not been able to regulate if problems occur. This is because the elements in the work relationship (permanent) are different from the elements in the pattern of partnership work (flexible), so that workers who make partnership work agreements are not protected. This condition is called Lack of Regulation, which is a condition of the absence of regulations governing an industrial activity.

Therefore, after going through various researches and discussions, it is necessary to redefine the working relationship in labor regulations. The definition of employment relations in current labor regulations requires that there are 3 elements that must be fulfilled, namely wages, orders and work, in the sense that these three elements are fulfilled in a permanent work relationship. In the partnership work agreement, the elements have shifted despite the existence of a work activity. The redefinition of working relationships is very important so that online transportation workers (Go-Jek riders) get legal certainty so that they can more easily get access to social protection. 
In its implementation, this social protection model needs to be supported by a policy model of partnership working patterns in the digital industry with a sharing economy system. The proposed policy model requires a bargaining process in determining the agreement. The success of the bargaining process must be supported by the infrastructure needed, including flexibility in regulation, meaning that regulations must be able to keep up with technological progress so that it can be used as a reference if problems occur.

The contents of the agreed agreement contain arrangements for the rights and obligations of the partners. Although workers' partners are those who need work, however, they are placed in a good bargaining position. For this reason, an ideal social security scheme is needed in the digital industry with a sharing economy system. This scheme requires the contribution of each party according to each portion for social security costs.

Agreements generated in the bargaining process can be applied, taking into account several factors, including: (a) Availability of technology and reviews of social media and online. In the digitalization era, the success and progress of a business is greatly influenced by technological progress and highly dynamic social media. Providers always upgrade service systems and periodic studies in this area continuously and continuously (kaizen), (b) The optimal service model is needed in online businesses because consumer trust determines the progress of digital business.

With the existence of a clear legal base regarding the pattern of partnership employment agreements, so that the principles of partnership are adhered to in the agreement, the social welfare efforts for online transportation riders can be guaranteed by the government and supported by various parties, especially the user community. So that in the end the social welfare of the riders of online transportation will increase. The proposed model is described as follows:

\section{The Partnership Work Policy Model in Industrial Sharing Economy}

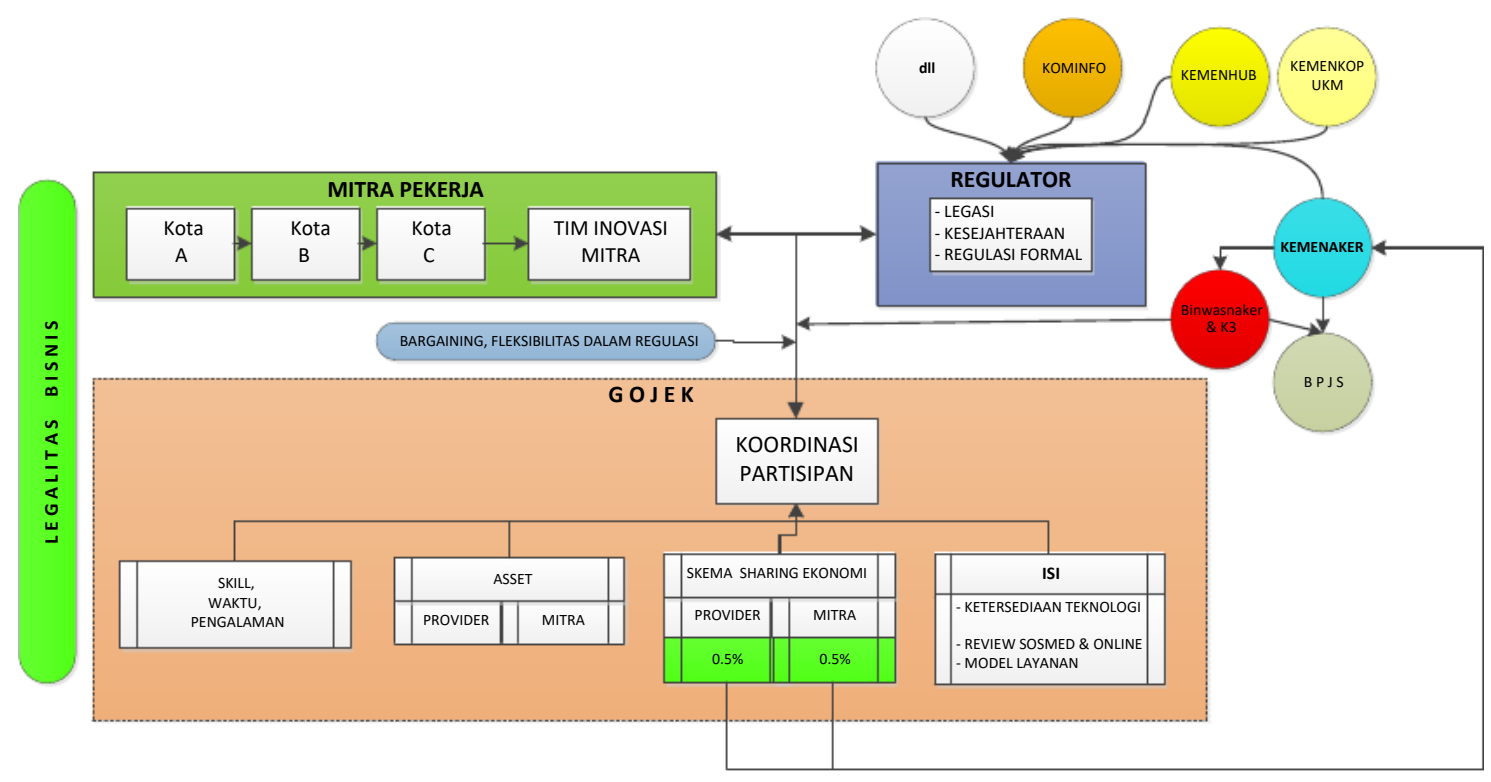

Source: Processed Research Questionnaire (2018)

\section{CONCLUSIONS}

This study concludes that the main challenges of the informal sector in Indonesia include (1) inefficiency and business competition, (2) limited access to consumers, (3) limited access to 
financial facilities and institutions. Viewing from the concept of social welfare, it is clearly found that there are shortcomings in the fulfillment of social welfare for online transportation riders. When viewed from the aspect of welfare which includes meeting needs, opening access to social participation, and overcoming problems, the condition of the welfare of Go-Jek riders in Bandar Lampung and Jakarta tends to decrease, even though at the beginning of the emergence of Go-Jek there was an increase in income which was quite significant because the rates offered are better and competition is still minimal because there were not too many GoJek riders.

The results show that there are problems in social protection for workers in the informal sector, especially two-wheeled online transportation which caused by a legal vacuum in the status of the partnership pattern so that it affect the welfare level of online transportation riders. Therefore, this study proposes the regulation of the rights of workers in the informal sector and regulation of the partnership working pattern with the sharing economy system so that the social protection of workers in the informal sector can be fulfilled. This is because in the future, the condition of the informal sector will dominate the world of work. The pattern of the partnership agreement with the sharing economy system is a new pattern of agreement in the digital economy era that will be increasingly prevalent in the future with a gig economy. For this reason, a government presence is needed in its regulation so that the welfare of two-wheeled online transportation riders as partners can be fulfilled.

The policy model of the partnership working pattern in the digital industry with the sharing economy system proposed by this author, involves relevant agencies in determining regulations which can later be used as a reference if problems occur. This policy model also requires the involvement of partners in the agreement process. By involving worker partners at a certain level, it is an appreciation to partners and placing partners in an equal position with the company (equality on partnership regulation). With this policy model, the legal base of the partnership employment agreement pattern becomes clearer and the principles of partnership can be adhered to by each of the partners in making agreements, so that there is no information asymmetry again between the company and the rider as a partner.

In this policy model proposal, there is an ideal social security scheme initiative for informal sector workers so that social welfare efforts for online transportation riders can be guaranteed by the government and supported by various parties, especially the user community, and finally the welfare of two-wheeled online transportation riders will increase.

\section{REFERENCES}

[1] Barker, RL, The social work dictionary. Silver Spring, MD: National Association of Social Workers, 1987

[2] Citradewi, A. \& JP Soebandono, "Influence of totali bag and psychological capital to a working satisfaction of gojek rider in South Jakarta" TAZKIYA Journal of Psychology Vol. 22 No. October 2, 2017. Retrieved from http://psikologi.uinjkt.ac.id/wp-content/uploads/2018/02/151163-Ardisa-Citradewi-Soebandono-OK.pdf

[3] Hanafi, M, Finance management (manajemen keuangan). Penerbit BPFE :Yogyakarta, 2004

[4] Ministry of Manpower of the Republic of Indonesia, SJSN Program Manual "Integrated interactive jamsostek blend", 2018

[5] Puskakom UI, The results of social benefit research on demand application: Go-Jek Indonesia case study. Depok: Puskakom UI, 2017 
Wahyu Sardjono, Initiating Social Protection Scheme in the Sharing Economy Industry (Case of Indonesia Go-Jek Rider)

[6] Matofska,B,Whatisthesharingeconomy?Retrievedfromhttp://www.thepeoplewhoshare.com/blog /what-is-the-sharing-economy, 2016

[7] SAP, "Dynamic Social Protection within the Digital Economy with Solutions from SAP". Retrievedfromhttp://www.sapevents.edgesuite.net/previewhub/socialprotection/pdfs/47768_GB _47768_enUS.pdf, 2016

[8] G. B. Khatri, Dr. D. S. Chaudhari, A High Capacity Digital Audio Watermarking Using Discrete Wavelet and Cosine Transform, International Journal of Electronics and Communication Engineering \& Technology (IJECET), Volume 4, Issue 6, November - December, 2013, pp. 7184

[9] S.K Mohapatra, R. Bhojray, S.K Mandal, Analog And Digital Modulation Formats of Optical Fiber Communication Within And Beyond $100 \mathrm{~Gb} / \mathrm{S}$ : A Comparative Overview, International Journal of Electronics and Communication Engineering \& Technology (IJECET), Volume 4, Issue 2, March - April, 2013, pp. 198-216

[10] Setiyino, B, Model \& Design of Welfare State (Model \& Desain Negara Kesejahteraan). Bandung : Penerbit Nuansa Cendekia, 2018

[11] Getaneh Berie Tarekegn and Yirga Yayeh Munaye, Application of Digital Cloud Libraries For Ethiopian Public Higher Learning Institutions (Ephlis), International Journal of Computer Engineering and Technology, 7(3), 2016, pp. 187-197.

[12] Suharto, E, Developing Society, and Empowering Society: Strategic Study of Developing Social Welfare and Social Work (Membangun masyarakat memberdayakan rakyat: kajian strategis pembangunan kesejahteraan sosial dan pekerjaan sosial). Bandung: Refika Aditama, 2005

[13] Nilesh D. Patel and Dr. Amisha P. Naik, A Low Jitter - Low Phase Noise Wideband Digital Phase Locked Loop in Nanometer Cmos Technology. International Journal of Electronics and Communication Engineering and Technology, 9(3), 2018, pp.1-12

[14] Swasono, S.E., Hasbullah T, et al, "Failure of labor transformation, dissimilar social protection" Policy Initiative Review July 2013

[15] Archanalakshmi K.S and Arathy Iyer, Auto Depannage Digital System With Endocrine Cellular Communication, International Journal of Electronics and Communication Engineering \& Technology (IJECET), Volume 5, Issue 12, December (2014), pp. 06-16 